University of Nebraska - Lincoln

DigitalCommons@University of Nebraska - Lincoln

Faculty Publications from the Harold W. Manter Laboratory of Parasitology

4-1995

\title{
Acanthobothrium nicoyaense n. sp. (Eucestoda: Tetraphyllidea: Onchobothriidae) in Aetobatus narinari (Euphrasen) (Chondrichthyes: Myliobatiformes: Myliobatidae) from the Gulf of Nicoya, Costa Rica
}

Daniel R. Brooks

University of Toronto,dnlbrooks@gmail.com

Sharon McCorquodale

University of Toronto

Follow this and additional works at: https://digitalcommons.unl.edu/parasitologyfacpubs

Part of the Parasitology Commons

Brooks, Daniel R. and McCorquodale, Sharon, "Acanthobothrium nicoyaense n. sp. (Eucestoda: Tetraphyllidea: Onchobothriidae) in Aetobatus narinari (Euphrasen) (Chondrichthyes: Myliobatiformes: Myliobatidae) from the Gulf of Nicoya, Costa Rica" (1995). Faculty Publications from the Harold W. Manter Laboratory of Parasitology. 222.

https://digitalcommons.unl.edu/parasitologyfacpubs/222

This Article is brought to you for free and open access by the Parasitology, Harold W. Manter Laboratory of at DigitalCommons@University of Nebraska - Lincoln. It has been accepted for inclusion in Faculty Publications from the Harold W. Manter Laboratory of Parasitology by an authorized administrator of DigitalCommons@University of Nebraska - Lincoln. 


\title{
ACANTHOBOTHRIUM NICOYAENSE N. SP. (EUCESTODA: TETRAPHYLLIDEA: ONCHOBOTHRIIDAE) IN AETOBATUS NARINARI (EUPHRASEN) (CHONDRICHTHYES: MYLIOBATIFORMES: MYLIOBATIDAE) FROM THE GULF OF NICOYA, COSTA RICA
}

\author{
Daniel R. Brooks and Sharon McCorquodale \\ Department of Zoology, University of Toronto, Toronto, Ontario, Canada M5S 1A1
}

\begin{abstract}
A new species of Acanthobothrium in Aetobatus narinari from the Gulf of Nicoya, Costa Rica, most closely resembles Acanthobothrium colombianum in the same host and $A$. urotrygoni in Urotrygon venezuelae from Cartagena, Colombia, by having relatively few proglottides per strobila, spinose cephalic peduncles, bothridial margins free at their posterior ends, and irregularly shaped rather than spherical or elongate cirrus sacs. Acanthobothrium colombianum differs from the new species by being as much as $35 \mathrm{~mm}$ rather than no more than $4.7 \mathrm{~mm}$ long and by having 31-48 rather than 13-19 proglottides, an average of 46 rather than 15 testes per proglottis, and bothridial hooks averaging $185 \mu \mathrm{m}$ rather than $137 \mu \mathrm{m}$ in total length. Acanthobothrium urotrygoni differs from the new species by being as much as $15 \mathrm{~mm}$ rather than no more than $4.7 \mathrm{~mm}$ long and by having $\mathrm{V}$-shaped rather than $\mathrm{H}$-shaped ovaries, bothridial hooks averaging $95 \mu \mathrm{m}$ rather than $137 \mu \mathrm{m}$ in total length, by having an average of 28 rather than 15 testes per proglottis, and by having poral ovarian arms extending anteriorly to the posterior margin of the cirrus sac and aporal arms extending to the lateral margin of the cirrus sac.
\end{abstract}

The Spotted Eagle Ray Aetobatus narinari (Euphrasen) occurs commonly in mangrove swamps throughout the tropical regions of the world. Included in the list of parasites reported previously in $A$. narinari are 3 species of Acanthobothrium van Beneden, 1849. During a preliminary study of the parasite biodiversity of Cosa Rican elasmobranchs, we discovered a previously undescribed species of Acanthobothrium inhabiting $A$. narinari in the mangrove swamps of the northern Gulf of Nicoya.

\section{MATERIALS AND METHODS}

Stingrays were collected in mid-afternoon at low tide using a beach seine stretched across a channel leading from a mangrove stand into the main channel of the Gulf of Nicoya. Cestodes were relaxed in sea water, killed in a relaxed condition with hot water, fixed immediately with AFA and stored in $70 \%$ ethanol. Whole mounts were stained with Mayer's hematoxylin. Serial cross sections of proglottides and scoleces were cut $7 \mu \mathrm{m}$ thick, stained with Mayer's hematoxylin and counterstained with eosin. Whole mounts and cross sections were mounted in Canada balsam. All measurements are in $\mu \mathrm{m}$ unless otherwise noted. USNM Helm. Coll. refers to the U.S. National Museum Helminthological Collection, Beltsville, Maryland; MNHG refers to the Museum of Natural History, Geneva, Switzerland.

\section{Acanthobothrium nicoyaense n. sp.}

(Figs. 1-4)

Description (based on 13 complete and 3 incomplete specimens; mean values in parentheses): Strobila acraspedote, apolytic, consisting of 1319 (16) proglottides, 2.55-4.73 (3.56) mm long. Scolex 294-369 (316) wide, composed of 4 trilocular bothridia each armed with pair of bifid hooks and surmounted by apical sucker and pad. Bothridia 340-431 (397) long by 106-181 (144) wide; anterior loculus 200-269 (235) long, middle loculus 56-81 (67) long, posterior loculus 81-116 (92) long. Average ratio of locular lengths 1:0.3:0.4. Apical suckers 57-71 (64) in diameter. Hook formula (modified from Euzet [1959] to include mean values) for 118 hooks:

$$
\frac{29-51(42) \quad 86-116(68) \quad 69-108(90)}{119-157(137)} \text {. }
$$

Received 15 June 1994; revised 15 September 1994; accepted 15 September 1994.
Cephalic peduncle 244-525 (330) long, spinose. Terminal proglottides $710-1,261$ (932) long by $238-463$ (321) wide. Genital pores alternating irregularly in anterior $27-44 \%(34 \%)$ of proglottis, protruding in largest proglottides. Cirrus sac irregularly shaped, 105-163 (142) long by 71114 (92) wide at genital pore, containing highly muscular spined eversible cirrus and convoluted internal seminal vesicle. Vas deferens coiled anteriorly to terminal genitalia. Testes 14-32 (22) in diameter, 12-22 (15) in number; 3-6 (5) preporally, 1-4 (2) postporally, and 7-15 (8) antiporally. Ovary H-shaped in frontal view, 194-416 (300) long, $\mathrm{x}$-shaped in cross section. Ovarian arms rarely extending anteriorly to posterior margin of cirrus sac, generally posterior to posteriormost testes. Vagina opening anterior to cirrus sac; prominent sphincter present. Vitelline follicles 5-17 (10) in diameter, extending in 2 single lateral rows from immediately postovarian to immediately posterior to anteriormost testes.

Host: Aetobatus narinari (Euphrasen) (Chondrichthyes: Myliobatiformes: Myliobatidae).

Site of infection: Spiral valve.

Locality: Punta Morales, Golfo de Nicoya, Costa Rica.

Holotype: USNM Helm. Coll. no. 84477.

Paratypes: USNM Helm. Coll. no. 84388; MNHG no. 18255.

Etymology: The species is named for the Golfo de Nicoya, Costa Rica, where it was first discovered.

\section{DISCUSSION}

Three species of Acanthobothrium have been reported previously from Aetobatus narinari. Two of those species, A. aetiobatis (Shipley, 1900) Yamaguti, 1959 and $A$. tortum Linton, 1916 , are readily distinguished from $A$. nicoyaense by virtue of being larger worms (A. aetiobatis is $15-30 \mathrm{~mm}$ long, $A$. tortum is $35-205 \mathrm{~mm}$ long), having more than 100 proglottides, square rather than elongate proglottides, foliose and relatively flat rather than compact and elongate ovaries, bothridial margins fused to the scolex rather than free at their posterior ends, and bothridial hooks averaging $250 \mu \mathrm{m}$ or more; in addition, $A$. tortum has an average of 163 testes per proglottis, and $A$. aetiobatis has an average of 25 testes per proglottis. Acanthobothrium colombianum Brooks and Mayes, 1980, from Cartagena, Colombia, resembles $A$. nicoyaense by having spinose cephalic peduncles, bothridial margins free at their posterior ends, $\mathrm{H}$-shaped ovaries with arms not extending anteriorly to the posterior margin of the cirrus sac, and irregularly shaped rather than spherical 

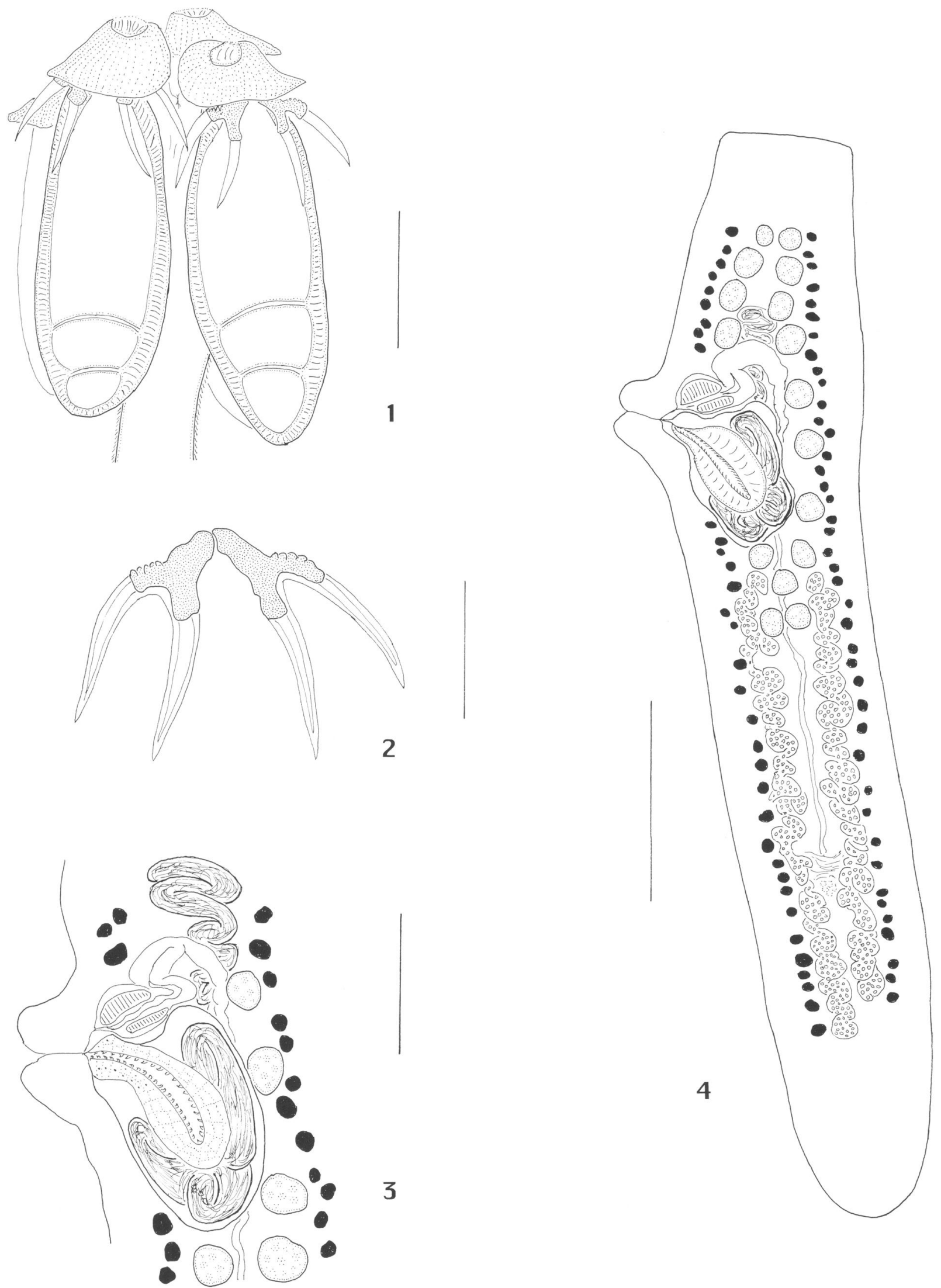

Figures 1-4. Acanthobothrium nicoyaense, holotype. 1. Scolex. Scale bar $=150 \mu \mathrm{m}$. 2. Enlargement of bothridial hooks. Scale bar $=75 \mu \mathrm{m}$. 3. Enlargement of terminal genitalia. Scale bar $=75 \mu \mathrm{m}$. 4. Terminal attached proglottis. Scale bar $=150 \mu \mathrm{m}$. 
or elongate cirrus sacs. Acanthobothrium colombianum differs from the new species by being up to $35 \mathrm{~mm}$ long rather than no more than $4.7 \mathrm{~mm}$ long, by having $31-48$ rather than $13-$ 19 proglottides, an average of 46 rather than 15 testes per proglottis, and bothridial hooks averaging $185 \mu \mathrm{m}$ in total length rather than $137 \mu \mathrm{m}$ in total length (Brooks and Mayes, 1980).

Acanthobothrium lineatum Campbell, 1969 in Dasyatis americana from the Chesapeake Bay, Virginia resembles $A$. nicoyaense by being relatively small, with a maximum reported length of $6.1 \mathrm{~mm}$ compared with $4.7 \mathrm{~mm}$ for $A$. nicoyaense, and by having spinose cephalic peduncles, bothridial margins free at their posterior ends, relatively few proglottides (6-19), H-shaped ovaries, ovarian arms about equal in length extending anteriorly to, or nearly to, the posterior margin of the cirrus sac, and an irregularly shaped cirrus sac. It differs from $A$. nicoyaense by having bothridial hooks up to $216 \mu \mathrm{m}$ long (with a mean of 148 $\mu \mathrm{m}$ ) rather than $157 \mu \mathrm{m}$ long (with a mean of $137 \mu \mathrm{m}$ ), and an average of 36 rather than 15 testes per proglottis (Campbell, 1969). Acanthobothrium paulum Linton, 1890 in Dasyatis centroura, D. americana, and Raja eglanteria from Woods Hole, Massachusetts and the Chesapeake Bay, Virginia is very similar to $A$. lineatum, and differs from $A$. nicoyaense by having an elongate rather than irregularly shaped cirrus sac, an average of 42 rather than 15 testes per proglottis, and bothridial hooks up to $229 \mu \mathrm{m}$ long (with an average of $157 \mu \mathrm{m}$ ) rather than up to $157 \mu \mathrm{m}$ long (with an average of $137 \mu \mathrm{m}$ ) (Campbell, 1969). Acanthobothrium urotrygoni Brooks and Mayes, 1980 in Urotrygon venezuelae from Cartagena, Colombia, resembles $A$. nicoyaense by having spinose cephalic peduncles, bothridial margins free at their posterior ends, relatively few proglottides (46 ), and irregularly shaped cirrus sacs. It differs from the new species by being a much as $15 \mathrm{~mm}$ rather than no more than $4.7 \mathrm{~mm}$ long and by having V-shaped ovaries, bothridial hooks averaging $95 \mu \mathrm{m}$ rather than $137 \mu \mathrm{m}$ in total length, an average of 28 rather than 15 testes per proglottis, and poral ovarian arms extending anteriorly to the posterior margin of the cirrus sac and aporal arms extending reaching the lateral margin of the cirrus sac (Brooks and Mayes, 1980).

Two features of $A$. nicoyaense are unusual for species of Acanthobothrium. The first is the relatively small number of testes per proglottis. Only A. quadripartitum Williams, 1968 , with 18 testes per proglottis and $A$. tripartitum Williams, 1969, with 1316 testes per proglottis, both in skates (Raja spp.) from the North Atlantic Ocean, and A. parviuncinatum Young, 1954, with 1214 testes per proglottis, in stingrays (Urolophus and Gymnura) from the coast of California, possess numbers of testes per proglottis similar to $A$. nicoyaense, but they all possess bothridial hooks less than $100 \mu \mathrm{m}$ in total length and differ in a variety of other characters. The second feature is the predominantly preovarian distribution of testes, a trait exhibited also by $A$. coronatum (Rudolphi, 1819) van Beneden, 1849, $A$. indicum Subhapradha, 1955, and $A$. mathiasi Euzet, 1956, species that do not resemble each other or $A$. nicoyaense in any other significant traits.

\section{ACKNOWLEDGMENTS}

We gratefully acknowledge Helena Molina Ureña, Escuela de Biologia, Universidad de Costa Rica, for her generous logistical help, assistance in the field, and friendship. We thank Nathan Lovejoy and Effie Gournis for their help in collecting hosts and parasites, Dr. Jose Vargas, vice-director of the Centro de Investigaciones del Mar y Limnologicos (CIMAR), and the staff of the CIMAR laboratory at Punta Morales for the kind use of their facilities, and for technical support in collecting hosts, and the members of the faculty of the Escuela de Biologia and Escuela de Microbiologia, Universidad de Costa Rica. This study was funded by operating grant A7696 from the Natural Sciences and Engineering Council (NSERC) of Canada to D.R.B.

\section{LITERATURE CITED}

Brooks, D. R., AND M. A. MAYEs. 1980. Cestodes in four species of euryhaline stingrays from Colombia. Proceedings of the Helminthological Society of Washington 47: 22-29.

CAMpbell, R. A. 1969. New species of Acanthobothrium (Cestoda: Tetraphyllidea) from Chesapeake Bay, Virginia. Journal of Parasitology 55: 559-570.

EuZET, L. 1959. Recherches sur les cestodes tétraphyllides des sélaciens des côtes de France. Thèses presentées à la faculté des Sciences de Montpellier pour obtenir le grade de docteur es Sciences Naturelles. Montpellier, France, 263 p. 